The Canadian Journal of Higher Education, Vol. XXIV-3, 1994

La revue canadienne d'enseignement supérieur, Vol. XXIV-3, 1994

\title{
Philosophy-in-Action in University Teaching ${ }^{\dagger}$
}

\section{SUE M. SCOTT, DONNA M. CHOVANEC, \& BETH YOUNG*}

\begin{abstract}
Fourteen professors expressed their "traditional," "humanist," and "critical" philosophies about teaching and learning when they engaged in dialogue with us and each other. The relationship between their philosophy of teaching and their practice in the classroom is the research question. Four themes that elaborate these philosophies-in-action emerged from a grounded-theory approach to data analysis. One theme, "Expert vs. Co-learner" describes these professors' views of themselves as teachers. A second theme, "The Relationship of Comfort to Critique," outlines some of the tensions that arise from attempting to create a comfortable classroom environment while also encouraging critical thought. "Learning for Change," the third theme, is about the differing forms of change in the learner that these professors seek as evidence that learning is taking place. Finally, in the section called "Coping with Constraints," our study participants identify institutional issues that have made it difficult for them to enact their particular teaching-learning philosophies in university classes.
\end{abstract}

\section{Résumé}

Quatorze professeurs commentent leur approche pédagogique de type "traditionnelle", "humaniste" ou "critique" et le lien entre leur philosophie d'enseignement et la pratique dans la salle de cours. Quatre thèmes essentiels issus de ces philosophies-en-action relient la conceptualisation théorique $d u$

$\dagger$ Thanks to Dr. Paula Brook, Research Director for University Teaching Services, for her contribution throughout this project.

* Department of Educational Policy Studies, University of Alberta 
problème à l'analyse des données. Le premier thème portant sur le rôle "d'expert vs celui de co-disciple" décrit les perceptions qu'ont les professeurs d'eux-même en tant qu'enseignants. Un second thème portant sur la relation entre "Bien-être et Pensée critique" décrit certaines des tensions engendrées par la volonté qu'ont les professeurs de créer un climat d'apprentissage favorable au bien-être tout en encourageant la pensée critique. Le troisième thème portant sur la notion de "Progression dans l'apprentissage" reflète la problématique d'évaluation du progrès des étudiants à travers ses diverses manifestations. Enfin, dans la section portant sur "Les Contraintes à l'action", les participants relèvent les difficultés rencontrées dans leur établissement respectif par rapport à la pratique dans la salle de cours de leur philosophie d'enseignement.

Reflection on the nature of one's teaching practice is essential to improving it. Opportunities to reflect, alone or in community, however, are rare when busy instructors must be concerned about their course content, departmental responsibilities, and research interests. Many teachers in university settings have little time or opportunity to talk about or to systematically reflect on - and possibly alter - the relationship between their philosophy and teaching practice. Our dialogues with a number of university teachers were an attempt to determine what philosophy or theory of curriculum best described these teachers' disposition toward and explicitly stated values about their teaching. Our purpose was to document and learn from these teachers' reflective practice, thus adding to the available knowledge of philosophies and practices related to university teaching.

A major assumption of this research is that one's philosophy drives one's teaching practice or, to put it another way, that teaching constitutes "philosophy-in-action." (This is an adoption and adaptation of Christopher Hodgkinson's [1991] treatment of educational leadership as philosophy/valuesin-action.) Philosophies are value-laden sets of assumptions that some teachers may enact without much critical insight or reflection. And without critique, there is little likelihood of enhancing or substantially changing one's ways of teaching. For example, critical reflection may make clearer the contradictions and inconsistencies in one's practice. More generally, studying the interplay of espoused philosophy and philosophy-in-use (an adaptation from Argyris and Schon's [1974] espoused theory and theory-in-use) allows us to illuminate the complexities of teaching in higher education.

Donald Schon (1983) makes a nice distinction between knowing-in-action and reflection-in-action. Adapted to our discussion here of university instruction, knowing-in-action involves a tacit knowing, a "knowing more than we can 
say" that is based on tacit recognition of research-based theories, judgment, and skillful performance in the classroom. We are often unaware of having learned to teach skillfully; we simply find ourselves doing it. Thus, when asked to make explicit what is implicit we engage in a kind of reflection that seeks understanding of routine responses, in this instance, to the phenomenon of teaching in higher education. Reflection-in-action, on the other hand, has a more critical function of questioning the assumptional structure of knowing-in-action. Thus, an instructor in higher education may restructure strategies of action/teaching in the classroom based on making explicit what is implicit (knowing-in-action), or he or she may reflect on the underlying assumptions, beliefs and philosophy of teaching that guide his/her practice. It is inquiry into the latter, reflectionin-action on one's philosophy of education or philosophy-in-action, that is the purpose of this study.

\section{Philosophies of Education: A Review}

According to Kneller (1971), there are five formal philosophies that are often applied to the field of education. From these philosophies, corresponding learning theories have been constructed which seek to help instructors develop a conception of a learning process for themselves and their students. The philosophy that one holds should address such questions as: What is the aim of education? What is the nature of humans and what is one's view of learners? What is the role of the teacher and the instructional strategies that emanate from one's particular philosophy of education? The five philosophies have been described as:

1) liberal/perennialism (mental discipline),

2) progressivism,

3) essentialism/behaviorism,

4) humanism (self-actualization),

5) reconstructionism/critical theory.

Each philosophy will be discussed briefly below as the theoretical foundation for this research.

The aim of liberalism/perennialism is to discipline or exercise the mind (a mental disciplinist approach) through the study of absolutes, often articulated in the form of principles. Liberal notions of disciplining the mind (Bigge, 1982) assume that the mind is like a muscle which must be exercised and stretched for it to develop appropriately. By studying the great works of literature, philosophy, history, and science, an individual develops his/her rational faculties and forms notions of good and virtuous citizenship. What one learns about the past 
will prepare a person for the future (Kneller, 1971). The learner is viewed as deficient cognitively, and the mind is viewed as superior to the body. Thus, the teacher, who is the expert in his/her discipline, must transmit expertise or knowledge to students. Because rationality is humans' highest attribute, the teacher's job is to ensure students develop "self-discipline, cultivate the intellect and control their appetites" (Kneller, p. 43). This kind of learning can only be evaluated philosophically, through the construction of well-reasoned and argued essays.

By the turn of this century, progressivists "rebelled against the excessive formalism of traditional education, with its emphasis on strict discipline, passive learning, and pointless detail" (Kneller, p. 47). The aim of education for progressives is to liberate the learner for improving society by analyzing and reconstructing experiences past and present; i.e., the learner interacts with his/her environment and continually interprets the meaning of his/her experience (Kolb, 1984). Education is not a preparation for living but is rather life itself (Lindeman, 1926). The role of the teacher is to become a partner-helper with the students as they "restructure their life spaces and gain new insights into their contemporaneous situations" (Bigge, 1982, p. 11). The learner is viewed as in charge of his/her own learning. Subject content becomes meaningful when used as a means for satisfying the needs and interests of the student. Students learn through reflection on their experiences (Mezirow, 1991) through primarily a social or dialogical process. Thus, learning through problem solving takes precedence over acquisition of subject matter.

Essentialism is similar to liberalism/perennialism in that it "stands for the reinstatement of subject matter at the center of the educational process" (Kneller, p. 57). Its aim is to reestablish the teacher as the authority in the classroom who would then distinguish what is essential and nonessential for students to learn in school programs. It focuses on the individual's adjustment to his/her physical and social environment and has been linked to behaviorism. In this theory of learning, it is assumed that the learner has been extensively programmed by the environment. If teachers reinforce desirable behavior, that will lead to a better society. The aim of education is to predict, change, and control students' actions by using available knowledge about the laws of human behavior. The role of the teacher is to manage and control this learning by designing an environment that elicits desired behavior and extinguishes undesirable behavior. That is, skills can be taught through an extrinsic reward and punishment system. Competency-based education, mastery learning, self-control and assertiveness training are examples of methods and strategies used in the classroom. 
Assessment/evaluation is based on the demonstration of changed behavior in accord with predetermined behavioral objectives. Objective tests that are criterion-referenced are standard evaluations.

In contrast, humanism is deeply interested in the freedom and integrity of the individual who is the designer of his/her own being or essence (Elias and Merriam, 1980). What a person becomes is his/her own responsibility. There is a concern in this philosophical worldview that free persons "must repudiate the subordination of the person to economic 'laws,' the tyranny of the majority over the dissenting minority, and the stifling of individuality by social conformism" (Kneller, 1964, p. 72). Thus students must constantly be concerned with the integrity of the individual within the gamut of human relations. The methods and techniques that have evolved from this perspective aim to promote growth and self-actualization of the individual in good human relationships with the teacher. The atmosphere in the classroom is usually warm and relaxed as the educational task is to assist and recognize each person's individuality, potential, creativity, and freedom. These goals are accomplished, not in isolation, but in community, in relationship to one other.

For the critical orientation to education, called reconstructionism in an earlier era (Brameld, 1965), true humanization takes place in the world only when each person becomes conscious of the social forces working upon him or her, reflects on these forces, and becomes capable of acting to change those forces which keep us from being liberated (Elias and Merriam, 1980). The aim of education here is to create a new social order that will fulfill the basic values of our culture which must be founded on a "genuine democracy whose major institutions and resources are controlled by the people themselves" (Kneller, 1964, p. 63). Students are educated and empowered to bring about this new social order both in their experiences in the classroom and outside the educational institution. The "dynamics of power and empowerment are intricately intertwined. Student empowerment, therefore, will depend upon negotiating, not avoiding, the power dynamics. .." (Briskin \& Coulter, 1992, p. 259). The essential strategy of a critical teaching practice, therefore, is critique. "Critique calls for a special and suspicious interpretation of those ideologies and institutions which support and maintain ruling power structures" (Gallagher, 1992, p. 240). As one critically reflects in dialogue with others and acts on that reflection, both personal and social transformation occurs.

Similar to critical theorists' social critique, feminist theory is "premised on the recognition that gender is a phenomenon which helps to shape our society. Feminists believe that women are located unequally in social formation and are 
often devalued, exploited and oppressed" (Kenway \& Modra, 1992, p. 139). Thus, feminism is a worldview, a lens through which all human interaction and social structures are interpreted. For feminist pedagogues, the relationship between teaching and learning requires not only a discourse about practice (what one does in the classroom) but also the social visions that one supports as he or she teaches. Because of a commitment to end social arrangements that lead women to be less than, put down and put upon, feminist pedagogy involves a personal political practice.

\section{The Study}

The research uses qualitative research theory and methods. A large Canadian university in western Canada is the site for the study. Fourteen professors were selected in purposive sampling to represent a cross-section of espoused philosophies as well as some diversity of disciplines and faculties. Two ads were placed in the campus newspaper in the summer, 1992, soliciting volunteers for the project who claimed to teach from various philosophical orientations. Invitational letters were sent to a list generated by reputation and from Women's Studies networks. Nineteen professors responded to the call. One was selected for piloting a protocol of questions and finally was added to 13 others who were included in the study. All of the research participants were keenly interested in their pedagogy and some had won teaching awards.

There were nine women and five men in the sample group. Seven teach in the faculty of Education, four teach in Arts and Fine Arts programs, one in Home Economics, one in Business, and one in Physical Education. Unfortunately, no professor volunteered from the sciences or mathematics; their views must be left to another study. Five are new professors with less than 4 years in the academy; two have just received tenure and seven have taught in the University for $10-20$ or more years. They teach in a range of class size from large $200-400$ persons in typical lecture auditoriums to small 6 person seminars around tables and chairs. The most common classroom holds about 25 students, who sit at desks.

Participants each were interviewed twice in one-hour interviews before and after a classroom observation. A technique of conversational interviewing was employed that included dialogue on the meaning each participant attempted to give to his/her practice. The purpose of the first interview was to gather general information about the instructor's pedagogy. In the course of the semi-structured interview, instructors provided us with an account of what they did in the classroom, why they did it, and whether or not their efforts produced the effects 
they desired. The second interview used the class observation field notes and the transcript of the first interview to verify, embellish, and probe more deeply into their pedagogy. At times, contradictions were also identified and reviewed. All interviews were taped and transcribed by the researchers themselves.

There were two meetings at which participants were invited to respond to the emerging categories. An initial draft of the paper was sent to everyone for reactions with several responding in writing. Some of the respondents resisted being labeled. However, they agreed to the clustering of assumptions and other elements in each person's philosophy (what they said) and action (what they did in the classroom). In discussion with the research participants, it was the clustering of the assumptions that each professor espoused that became the important aspect of this study. It is clear that there were distinct differences in the philosophies that emerged. A second opportunity for reaction and conversation existed when the three authors presented the findings at the University Centre for Research on Teaching and Learning.

Various methods were used to analyze the data including open and axial coding (Strauss \& Corbin, 1990) and hermeneutics (Gallagher, 1992). Firstly, in order to understand the various philosophies, open coding (Strauss \& Corbin) in grounded theory proved the most effective. Open coding involved placing units of analysis from each person's two transcripts and observation field notes into a matrix table labelled with their names on the horizontal axis and the dimensions of a philosophy of teaching on the vertical axis, i.e., assumptions about teaching, view of the learner, role of the teacher, methods and strategies, evaluation, constraints and resistances. Alternating back and forth across the participants' data generated hunches, themes, or subcategories from which emerged the four philosophy-of-action catetgories. This intuitive and dynamic movement between inductive and deductive analysis facilitated axial coding. In axial coding, Strauss and Corbin advocate a "paradigm model" which includes placing subcategories in the following sequence: A) Causal conditions $\longrightarrow$ B) Phenomenon (category) $\longrightarrow$ C) Context $\longrightarrow$ D) Intervening conditions $\rightarrow$ E) Action/Interaction strategies $\longrightarrow$ F) Consequences (Strauss \& Corbin, p. 99). Thinking systematically about data using this model, it is possible to identify a phenomenon that relates logically to its subcategories and includes a set of dimensions and properties. Finally, selective coding involved identifying the core category or central phenomenon of the study. 


\section{The Philosophies}

In practicing their pedagogy, all participants in the study draw on aspects of more than one philosophical base. However, data analysis to seek the essence of their stated assumptions and beliefs reveals 4 types of philosophies that inform these study participants' pedagogies. They are: 1) traditional, 2) humanistcritical, 3) critical and 4) feminist. Although we use these more descriptive names for our philosophies, there is a direct relationship to the literature reviewed above. Liberal/perennial philosophies combined with essential philosophies form what are the most familiar teaching philosophies in higher education, what we call traditional philosophies. The vast majority of professors who teach in the academy teach from these perspectives. Those teachers with a humanist-critical perspective share the assumptions characterizing a progressive philosophy. While these professors are interested in student growth (a humanist characteristic), there is also a commitment to a critical perspective - raising awareness of pertinent issues by analysing the social construction of society. Those teaching solely from the critical and feminist perspectives are reconstructionists. The purpose of education for these professors is the creation of a new social order based on critique of what is and visions of what ought to be. These educators believe that one can only change social structures by unrelenting critique of power through a theory of society and a theory of self.

While almost all of the participants in this study indicate an awareness of traditional pedagogy, four participants specifically identify themselves as traditional educators. All of the instructors report assumptions and strategies typically located within the humanist school of thought but there were no exclusively humanist participants. However, four instructors who did not align themselves with any one philosophy seem to exemplify most clearly the humanistic approach, in combination with some notions more commonly associated with a critical pedagogy. This led to the development of our humanist-critical category. Two participants confidently identify themselves as critical educators and four as feminists.

For each of the four philosophical orientations articulated by participants in our study, distinct perspectives on the aim of education, methods and strategies, the role of the teacher, the teacher's view of the learner, and evaluation could be identified. Moreover, four philosophy-in-action phenomena emerged that further clarified and deepened an understanding of the uniqueness of each of the philosophies. 
Figure 1

Phenomena

\begin{tabular}{|c|c|c|c|c|}
\hline PHILOSOPHY & Expert vs. Co-learner & Comfort for Critique & Learning for Change & Coping with Constraints \\
\hline Traditional & $\begin{array}{l}\text { - Teacher as information } \\
\text { giver } \\
\text { - Teacher as expert }\end{array}$ & $\begin{array}{l}\text { - Get to know students } \\
\text { - To promote critical } \\
\text { thinking, logical } \\
\text { reasoning }\end{array}$ & $\begin{array}{l}\text { - Advanced rational } \\
\text { thought }\end{array}$ & $\begin{array}{l}\text { - Large classes don't } \\
\text { allow for testing of } \\
\text { critical thinking } \\
\text { - Academy becoming } \\
\text { an industry }\end{array}$ \\
\hline Humanist-Critical & $\begin{array}{l}\text { - Teacher as co-learner, } \\
\text { facilitator } \\
\text { - Student expert in life } \\
\text { experiences }\end{array}$ & $\begin{array}{l}\text { - Supportive classroom } \\
\text { milieu } \\
\text { - For personal and social } \\
\text { critique }\end{array}$ & $\begin{array}{l}\text { - Personal growth } \\
\text { - Social purpose }\end{array}$ & $\begin{array}{l}\text { - Large class size } \\
\text { - Not enough time } \\
\text { - Lack of feedback } \\
\text { - Grading }\end{array}$ \\
\hline Critical \& Feminist & $\begin{array}{l}\text { - Teacher's role is power } \\
\text { - Share power with students } \\
\text { - Struggle with grading } \\
\text { system }\end{array}$ & $\begin{array}{l}\text { - Discomfort through } \\
\text { conflict and struggle } \\
\text { - To examine values, } \\
\text { beliefs, assumptions } \\
\text { - For critical analysis of } \\
\text { societal structures }\end{array}$ & $\begin{array}{l}\text { - Personal and social } \\
\text { transformation }\end{array}$ & $\begin{array}{l}\text { - Time-tabling of classes } \\
\text { - Student expect lectures } \\
\text { - Isolation from colleagues } \\
\text { - Labeling }\end{array}$ \\
\hline
\end{tabular}




\section{Philosophy-in-action}

Four phenomena which illuminate the participants' pedagogical practice within their espoused philosophies have emerged from this research: 1) expert vs. colearner, 2) relationship of comfort to critique, 3) learning for change and 4) coping with constraints. Figure One juxtaposes these themes with the four philosophies.

\section{Expert vs. Co-learner}

The phenomenon of expert vs. co-learner is primarily supported through the participants' descriptions of their role as teachers and their view of learners. Professors who teach from a more traditional stance tend to view themselves as experts while those with more humanistic and critical notions of education make more assumptions about mutual learning. This phenomena is intricately linked with notions of power. All instructors in this study recognize that they hold the authority in the classroom and have the power to grant grades within a traditional institution that bestows authority to the professor. However, their assumptions about the legitimacy and use of this power vary.

The four traditional instructors in this study emphasize information, logic and rational thinking processes. Moreover, they believe that the flow of information is from the teacher-expert who has more knowledge to the student, i.e., "from the teacher down to the students." Based on this assumption, the traditional instructors assume that it is their mandate to discern what is important for students to learn, to set the conditions for maximum learning and to control the learning environment. In other words, classroom power is clearly situated with the professor.

For example, one traditional instructor provides a clear description and rationale for his professorial practice based on the early liberal notion of disciplining the mind. Flatly stating that the "teacher is qualitatively superior to students," he also assumes that "students are deficient in their thinking and reasoning abilities." He emphasizes that an instructor must have talent, "a brilliant linguistic presence." Therefore, he emphasizes the importance of "giving new information beyond the present knowledge base" and "making students stretch their thinking ability." Another traditional educator elaborates on behaviorist notions of education which include the classic references to feedback, reinforcement and antecedents in influencing behavior. In the classroom, such environmental factors are established by the teacher. This notion of power is exemplified in the following quote. 
I really believe in the ecology of shaping kids' behavior patterns. I believe parents transmit cultural values to their kids through the way they shape their behavior, through the way they construct the home. I think teachers do the same thing. They can construct their classroom that demands certain kinds of cultural normality from students. In other words, they enculturate through the patterns, routines, the way they set up their classroom....In that sense I'm a behaviorist. I think teachers should inform themselves to the degree to which they do this. And it's through their behavior and constructing their environment that they influence their kids.

Traditional grading practices reflect the influence of the expert stance held by this group. In general, there is a heavy reliance on essays and exams, in which the instructor determines the level of knowledge gained. These instructors state: "You choose the quantity, I'll judge the quality" or "I want to see the product of their work; I need some specific behavioral objectives achieved to evaluate." Although there is almost universal skepticism that multiple choice exams can determine the level of critical or logical thinking, one stated that "the mechanics of the class [of 400] create no conflict because there really isn't any true alternative." In smaller classes, however, these instructors use reaction papers, contracted reading assignments and other evaluative forms that reveal structures of thought more clearly.

All of the fourteen instructors in this study agree that the university professor has some expertise and more knowledge of the content than do his/her students. However, instructors who espouse humanist-critical and critical/feminist orientations advocate equal respect for the life experience and knowledge which the student brings to the classroom. For instance, one states:

We put far too much emphasis, importance on knowledge that is exterior to self. It's very important that we value personal knowledge....always have to make links, starting with your own personal knowledge.

Such instructors view the teacher/student relationship as complementary, exemplified by the comment, "I learn from them as much as they learn from me." This notion of complementarity was particularly emphasized when the instructor held a humanistic orientation.

Quite specifically, I reject the notion of the professor as the expert...It's easy to fall into the trap of thinking that you're someone special 'cause you're the professor...all contributions are equally important... 
I don't see myself as an expert on everything and I try to relay that to students. I want it to be a collaborative learning experience...they have experiences that I don't have...on the other hand, in some areas I have more background, have done more reading, have more knowledge and I can determine what is most appropriate/helpful for them to read...I want them to see that there's nothing wrong with my not having all the answers. I'm willing to continue to learn.

Succinctly summarizing the perspective of many, one critical educator labels himself "a co-learner with additional resources."

Believing that students and teachers learn together, those professors whose classroom practice incorporates many humanistic elements, rely heavily on collaborative learning strategies, such as, "group dialogue which supports the value of partnership" or:

...activities in the class where everyone can contribute, where everyone is working, and perhaps in groups that are doing different activities and when we bring them all together, it forms the whole...sense that everyone has something to contribute and that we can learn from everyone.

These professors believe that it is their responsibility to establish a comfortable, relaxed, yet challenging, classroom atmosphere conducive to discussion, critique and mutual learning. As one professor states: "[I] affect that process, rather than just observe..."

These professors also emphasize their role in promoting student growth. They view themselves as "facilitators" who are responsible for "pushing, nudging, challenging" their students in order to "help them in their journey."

I want to edge them on, push them more and more to do the best they can do, tap unknown potential and feel satisfied. My role is bringing out the potential. On an academic level, is my main concern, but on a personal level, as well.

Generally, the instructors in this study view students as self-directed individuals who take personal responsibility for learning. Comments, such as "I see the learner as the authority on their life," "learning to a great extent comes from them not me," "[I view] the learner as an active agent," were noted across the four philosophical categories. Some professors who are concerned about power relationships, however, struggle with a tension between "two beliefs," i.e, their philosophical positions on the role of the teacher and the view of the learner, such as in the following quotes from a critical and humanistic perspective, respectively. 
I can only act as a facilitator and take my cues from them and I don't hold myself responsible if they don't - I mean I do and I don't - I mean I think that students are all on their own journey and so their degree of readiness to see something is dependent on that...I'm not responsible for another person's growth. And yet it also is a challenge for me because I do think a teacher's role is really crucial...There's always the question 'Is there another way to facilitate this so that it would work for more students?'

[I'm] trying to walk that fine line between. . . giving to them something that we have to offer and drawing out of them knowledge that they already have...

Yet, professors in this study who practice humanistic, critical or feminist pedagogies also clearly recognize their institutionalized authority. In the words of one feminist professor: "I take authority for granted; I am the teacher." Another professor, with a humanist/critical perspective, says: "They joke that I give all my power away. In fact, that's not the case; I do have power, the role is power." While they recognize these authoritative influences, they also challenge them. Unlike their more traditionally oriented colleagues, a majority are new and generally dispute the notion imposed by the university that teachers should have greater power in the system. They make such statements as: "I share power with students" or "the students have a right to know instructors' stances." Critical and feminist pedagogues believe that they should "divest authority" and "equalize the power relations in the classroom."

Critical and feminist educators particularly emphasize professor-student power relationships, often using this reality as a point of entry to exemplify societal power dynamics. Typically, they address power issues directly. "I do have power that they don't have...I thematize my power." This is accomplished through classroom discussion which highlights the power and authority implicit in the relationship between professor and student and emphasizes the contradictions.

I teach them a lot about power...dominance and subordinance in society and then how that translates into families...how that affects us in class and how there are parts of that I can't do anything about but other parts I think I can do something about...to lessen the power differences between us within the class.

Often, these teachers analyze seating arrangements or discussion methods in an effort to decenter authority. For example, one instructor often avoids sitting at the end of the table in a seminar classroom and another places the desks in a complete circle and invites a quick "gut response" to the text from everyone in turn before proceeding. 
Once instructors challenge their own expert stance and assumed power, evaluation and grading become particularly problematic; "[they] undercut what you're building." Many feel similar to this instructor: "I just agonize like crazy now; I find [marking] the most difficult aspect of my work." While conscious of the undeniable and expected authority invested in the evaluative process ("finally, it comes down to my assigning the grades and evaluation"), instructors use many and varied means to cope with this contradiction. In general, they attempt to decrease competition and to enhance choice-making. Most involve the students in generating exam questions or offer choices in essay topics or marking systems. The instructor's evaluation is sometimes "tempered" with self and/or peer evaluation. Most attempt to stimulate critical reflection and personal engagement through both graded and non-graded assignments. One professor encourages the students to write repeated drafts for supportive feedback before grading. Journals are encouraged but usually not graded or not read. For example, one instructor requires a reading $\log$ instead of the actual journal; that assignment involves having students hand in one page summaries of the journal reflections twice in the semester.

However, the consequences of struggling with the grading system are tension and emotional reaction to this way of teaching. Some question their own ability to do critique or the superiority of their own knowledge. There is pain and struggle attached to grading. Many of these instructors "hate it" since it imposes a hierarchy of excellence within classrooms which they have attempted to run collectively. And students are often unfamiliar with the professors' attempts to "share" the grading responsibilities.

Well, I wasn't sure whether it was too threatening for them at the beginning because they're always treading that line between security and authority and free choice. And they're not used to free choice.

Thus, instructors feel they are forced to live with a dilemma. To deal with the dilemma, they seem to hold in dialectical relationship two opposing forces: the co-learner stance they assume in the classroom with the expert stance bestowed on them by the university, which gives them the power to grant grades.

\section{The Relationship of Comfort to Critique}

The second phenomenon that emerged from this study of philosophy-in-action is the relationship of comfort to critique. Almost all instructors attempt to stimulate some form of critical thought while at the same time creating a comfortable classroom environment. According to their philosophical orientation, however, the relative importance of comfort and the definition and purpose of critique 
varies. This phenomenon highlights the interplay between philosophical assumptions and pedagogical methods/strategies.

In terms of comfort, almost all of the instructors in this study incorporate many typically humanistic characteristics into their pedagogical perspectives. That is, they assume that the optimal learning milieu is respectful, comfortable, supportive, and relevant, thus facilitating a learning experience which fulfils individual student needs. Participants generally accord respect to individual choices, note concern for the development of self-esteem, acknowledge the importance of relationships and emphasize collaboration. They speak of being "playful," of making the classes "challenging and fun," of providing cookies and coffee, or playing background music in the classroom. It is also common for these particular instructors to note the importance of making personal connections with their students, such as knowing individual students by name.

The majority of instructors in this study also hope to encourage or develop the students' abilities in "critical thinking" or "critique." Those holding the more traditional philosophies focus on "making students think more rigourously." This notion of "thinking" emphasizes logic and rationality as in the phrases: "logical reasoning" and "rational thinking."

I often ask them to write a position paper and they must defend a position from at least 2-3 sources: theoretical basis, empirical basis, experiential basis. So there's a different kind of learning where they have to think it through logically.

These professors believe that it is their responsibility to "keep asking questions" in order to foster "an inquisitive view of the world." One spoke specifically about the need for students to learn "to ask abstract/logical questions without the ego."

Well, in a large lecture class, there really is no other way to assess their critical thinking except through their questioning... Question asking is the primary way. It's the fine tune to critical thinking. I don't give quizzes to test their critical thinking. I have to take a raw question and cultivate it, help the student to refine the question.

"Critical reflection" and "critique" are words more commonly used by the other professors in this study. Two specifically used the colloquial phrase "to develop a critical eye." Firstly, these instructors often emphasize the importance of critically examining personal views in relation to the subject matter. The words of one instructor echo the view of others: "I teach them throughout the class to identify values, beliefs and assumptions and...they analyze and critique those values, beliefs and assumptions." Some instructors spoke at length about their hope that students "are able to critique, to look at different points of view." 
I'll focus on pushing them to 'think beyond' daily activity, to question and reflect...I really aim to make people think, to look at things critically, from a different perspective from their own...and to continue to question as they go...

As implied in the above quotes, these instructors accept pluralistic viewpoints. They believe that "there is no single vision," that it is not their job to "preach" a particular viewpoint but rather to encourage students to look at the relative value of multiple perspectives. A more critically oriented instructor, however, adds that "I like to push people to follow through to a conclusion...not just relativist...[but] understand the full implications...agonize."

Part of this process includes the strategy of problematization. Students are asked to "pause and rethink," "interrogate their experience" and "bring personal critical perspectives."

They need to know that whatever they do, they have to do some critical analysis, not just summaries, they have to think about whether it makes sense or not, whether there are contradictions...

Furthermore, these professors incorporate social critique into their course content. Within this approach is the more feminist emphasis on consciousnessraising and critical pedagogy's "critical reflection on society's messages." It is for this reason that we were unable to delineate professors practicing from a strictly humanist perspective in this study. Even among the four who most clearly articulate a humanistic orientation, there are important elements in their philosophical stances which align them, at least in part, with critical educational philosophies. These instructors look at their subject matter from a "socio-political perspective," which is supported by the assigned readings and classroom activities. For instance, a francophone teacher-educator introduces an analysis of Canadian bilingualism.

I suppose I've become very politicized along the way...so it's difficult for me to consider bilingualism only at an individual level...one at a societal level and one, as well, of relationships of power, at a policy level...Preparing educational leaders, I want them to see a global picture, have an idea that it may be more complex than it appears....and raising their consciousness...I tend to situate things globally.

Another example is an ESL professor's promotion of the examination of social values, attitudes and policies towards immigrants.

It's important for students to have opportunities to critically examine their values, the taken-for-granted we grew up with. It's particularly important for those who are working with those from other 
cultures...not just teaching facts, dealing with whole social fabric. I hope they wouldn't just learn about ESL or adult literacy, but think about their attitudes toward people.

Typically, social critique is the essence of the content and process in feminist and critical classrooms. Content centres on a critical analysis of the societal power relations of race, gender and sexuality. "One of the things I try to do is make power a theme." Dialogue, journal writing and reflective papers are used to promote critical reflection. The literature or course texts are chosen to present the information and generate the emotion that will bring theory to life. Students "read literature about oppression" in a family studies class, such as Killers of the Dream (by Lillian Smith), fiction that "doesn't let you off the hook" in a women's writing course, such as Jane Eyre (by Charlotte Bronte), or autobiography, such as Incidents in the Life of a Slave Girl (by Harriet Jacobs). The adult education instructor who provides opportunities to sample "multiple perspectives" hopes that his students will "leave with a sense that these different pedagogical styles are always implicated with power." The professor of a large introductory sociology course hopes that her lectures which introduce a feminist or "critical perspective" to the work of the traditional theorists will reveal the hidden assumptions behind the theories.

The instructors who want to foster critical thinking and personal or social analysis within a largely humanistic framework believe that there must be comfort for critique. These professors believe that a successful class is both "friendly and critical." One feels that students can only "critique from a base of support." Another states:

I always try to reduce the affective filter...that people are willing to take risks, to express opinions and they won't if they don't know each other. My thing is to make the students feel at ease...If there's an affective block, there's nothing.

This varies decidedly from the emphasis on "discomfort" or "disequilibrium" noted by feminist and critical educators who hold an underlying belief that "conflict and struggle" are essential in the process of transformation. One Women's Studies professor challenges the traditional "feel good" notion of learning and believes that "....at least certain kinds of learning may happen more readily if you don't feel good." Therefore, an "uncomfortable kind of questioning" is used to "destabilize people's perspectives." A feminist professor speculates:

It's a case indeed of....shaking, indeed directly, an enormous number of received wisdoms and ideas and things your mom and dad 
told you and did and all that sort of business. And very often, that makes indeed for a very exciting classroom sometimes. But, you know, in the context of stretching their minds, that's fine.

Another instructor states that when students are "interrogated by an alternate point of view," the learning experience is often "conflict-ridden and contestable." Referring to a recent class with a guest lecturer, he added:

The presentation was successful 'cause people were disturbed...right pissed off...we quite successfully started yanking at their assumptions.

In such classrooms, students may become "bothered," overwhelmed or angry. Predictably, they often display resistance to the non-traditional, critical approach as well as to the content. Based on her experience, the feminist literature professor believes that conflict and resistance is an expected phase of the consciousness-raising process and that a full year is required to "synthesize" the uncomfortable feelings and information generated. Other professors are also intently aware of the hazards of this approach and take their responsibility in this regard seriously.

When you are dealing with analysis that changes people's lives, then you have a responsibility for doing it ethically and carefully. You know, you can't tell how much impact it will have on anybody and, in a sense you're not responsible for what they do with it. But I think you are responsible for how it is presented and negotiated.

One instructor reflected on the point at which it becomes an ethical issue: "How uncomfortable are you allowed to make people?" Professors who like to promote dialogue or debate on "contentious issues" in the classroom are also very aware of their responsibility to create a safe environment. While they encourage participation, they also respect silence. Some state their opinions and biases clearly, believing that students should know where their instructors stand. They suggest that sometimes they must "intervene" or "moderate" in order to keep the discussion on track, deal with problems or maintain courtesy and respect between students.

\section{Learning for Change}

The third phenomenon is learning for the purpose of change. This phenomenon draws on the participants' assumptions about the aim, intent or purpose of education/learning. In addition to students acquiring knowledge of their discipline, all participants agree that the aim of education is to promote some form of change in students. As one professor states: "The question that always comes to 
me is 'Is there change happening with the students?" However, the specific form that this change should take varies across the philosophical groups.

The following quotes from among the more traditional educators indicate that they often aim for the achievement of advanced forms of rational thought.

By the end of the semester, I can see students have changed by the nature of the questions they ask.

[Student learning] involves abstractions and use of principles and rules and higher order knowledge structures...I view it an achievement if most people get toward some level of sophistication.

Others note the importance of students being able to use what has been learned.

Within the humanist-critical philosophical grouping, both personal and social purposes to education are identified. The humanistic elements of their philosophical stance orient these teachers toward personal growth objectives. The outcome for students is not expected to be "some immovable standard out there but a sense of growth, of new challenge." The idea of an expanded or more inclusive belief system is often described. Instructors hope that students are ultimately able to "look at the same issue from another angle" and to "acknowledge that there are other perspectives and that maybe those perspectives have some value." One professor refers to this as "transforming their mental schema." More deeply, there is also an assumption that the essence of a belief system, or acquired knowledge, lies in identifying personal meanings, in other words, that "learning is a process of constructing meaning." Professors comment that "what's important is that students find a meaning in their learning" because they believe that "the more personally it is connecting, the more meaningfully lasting it will be." One comments that: "I think a sign of growth is not necessarily that you give up your beliefs or believe something different; what is important is that you understand that those beliefs are rooted much more solidly." Espousing an orientation similar to personal growth, one professor focuses on identifying personal needs.

I still subscribe to the philosophy that students should come out at the other end taking responsibility for what are their needs and how do they go after getting them met...I want them to become, if you will, self-activated students who can name their needs, ...can pursue them, can reflect on their accomplishments and again say what are their needs as, first of all, students and then as practitioners.

By including aspects of a critical pedagogy, these 4 instructors also identify a social purpose. Firstly, there is an assumption that the personal belief systems addressed above will include aspects that are "socially constructed" or reveal 
"the social fabric." By challenging or expanding beliefs, therefore, social concepts or structures may also be changed. For example, within this group, an administration professor expects that, by including the work of interpretive and critical policy theorists, the school administrators in her class will develop "a broad framework" of alternative leadership structures. A francophone and ESL instructor both encourage their students to challenge language and cultural policies.

Critical and feminist educators espouse a transformative intent, i.e., they are concerned about both personal and social transformation. Constrained by the university setting, they focus more directly on transformation of individual consciousness. They hope to "facilitate critical enlightenment" or "enable...transformation within the group." For them, this means that students "will see the way that structures of thought and exclusion work" and "make those applications to their own histories." They realize that "ideological change" reflects integration and synthesis of information and insight.

Some professors also articulate their intention that students act upon this transformation in the social world. They anticipate an effect on self and family and a desire for "moving on" and "social change." But they are critically aware that a concrete social action component is missing in their classroom work. "Unfortunately, I think, the limitation of a classroom setting is that we don't go from there to do any kind of political change." They attempt to mitigate this limitation somewhat through reflection, discussion, assignments and textual material which focus on "strategies for social change," which students might then use in the future. In the following excerpt, a family studies instructor discusses her sense that critique leads to enlightenment which provides hope and energy for future action.

...the aspect of critical social science that needs to make some social change. And I would see that social change as being their actions towards children...their expected actions either as parents...or as teachers...or as family educators...Their culminating project is a personal reflections paper where they take an area of their development...then they analyze and critique those values, beliefs and assumptions and...what would they change about that and how do they see this as influencing their action with children in the future?

However, some instructors admit that they "don't know how that will translate in [the students'] personal lives." Most understand that they cannot control the student's process of change; "every student has their own answers, their own timing...everybody's gonna see things differently, in a different time, in a different way and I can't predict when that will be." Another concedes: "It's naive to think that all people are transformed; some people are not going to change." 


\section{Coping with Constraints}

The last phenomenon that emerged in this study involved coping with the constraints of the university system. Virtually all instructors identified institutional issues that made it difficult for them to actualize their particular philosophy-inaction at least some of the time. "The struggle for me, anyways, is to also admit the system I'm in." Constraints, and the attendant coping strategies, that were most often identified involved class size, scheduling, student expectations, feedback/support, grading and philosophical differences.

Class Size Those who teach large classes recognize the difficulty of using anything but multiple choice, true-false exams because of the time constraint. They are aware that it is difficult to assess critical thinking or analysis in objective, "retention and recall" exams. One traditional professor indicates his frustration: "There's a contradiction in that in a class of 400 the testing procedure doesn't allow you to test for that which you most hope you are achieving." Even in mid-sized classes, one admits "I just didn't have time to mark 60 term papers." One feminist professor teaches in a large lecture theatre "...which thus limits...innovations in teaching style." Therefore, in these larger classes, she becomes more traditional in form using questions, handouts, overhead transparencies and limited student involvement. She, like many others in this study, believes that large classes require the underpinning of closer contact in small groups. All of the professors advocate smaller classrooms as valuable in achieving their goals. Even those in large lectures maintain that it would be helpful to break the group into smaller seminar groups for more discussion about the content. Even in mid-sized classrooms, breaking into "family groups" or study groups are ways these instructors promote dialogue. Some professors try to reach their students by occasionally teaching from the aisles or by memorizing names.

Scheduling Those who believe dialogue promotes transformation believe that 50 minute classes are too short to get into any depth. However, timetabling decisions seem to have "no regard to how you're trying to teach the course or what you want to accomplish in it." The scheduling of core courses against electives or insensitivity to adult schedules, as in drama students who stay up late rehearsing but who must be in class at 9:00 a.m. the next morning, also were mentioned. A feminist professor who engages in a consciousness-raising cycle with her students insists that her course be scheduled for the full year.

During the study, some professors appeared harried by numerous and varied professorial commitments. Sometimes they challenge the priorities established by the university which reduce their opportunities to commit time to 
teaching excellence. One speaks about "stupid committee stuff." Another refers to the pressure to publish. Two professors had recently been told they were spending too much time with students. One of these states: "I am getting the picture that teaching is not so valued and that I/we should not spend so much time on it,"

Student expectations Critically oriented instructors believe that students are so deeply socialized to expect "structure and authority" (largely from traditional schooling experiences) that they remain reluctant to "break down" the power dynamic between professors and students. Many professors feel that students themselves expect lectures to gain information in class. When the instructor promotes dialogue on issues, students seem, at first, hesitant or even angry. Some adapt to students' expectations by becoming more structured at the beginning of the term with class outlines and more lecture. However, by "easing into it," toward the end of the semester they have achieved a more participatory curriculum.

Feedback/Support Often instructors voice frustration about the lack of feedback. They state: "The classroom is like a sound room" or "you put it out but you don't know what you're getting." The whole issue of feedback also includes an isolation from their colleagues which fosters loneliness. In particular, they feel there is no meaningful interaction with their peers to discuss their pedagogy. More than one professor identifies the need for dialogue and reflection.

What helps people with their teaching is dialogue, meaningful discussion, rooted in practice, rooted in the concrete specifics of practice, with other people, students and instructors...and then reflection, critical reflection, is what needs to be done.

However, as another states, "those opportunities don't seem obvious to me in this institution." Sometimes when such supports are established, such as a "community of feminists," a price is paid in labeling and minimization.

Two of the newer instructors also spoke about their relative powerlessness in the system as "marginalized" or "subordinate" persons, in this case a feminist and a sessional.

One effect when you're trying to get hired or when you move into a new community is to feel extremely anxious and under the gun, especially pre-tenure. To feel that powerless that you always have to watch your back and sort of do what the powers, what the institution wants from you... 
Grading Contradictions and concerns about grading are a repeated and essential theme. Many problems related to the expert stance of traditional evaluation methods are described in some depth in an earlier section. Also, the grading problems inherent in large class sizes are alluded to above. Various strategies to cope with grading were mentioned. Other evaluation issues identified frequently are the requirement to grade on the bell curve and pre-determined ranges for class grade point averages. Some also note the "subjectivity" of grading, finding a "defensible criteria" and trying to be "just." Many of the professors in this study might agree with the following analysis of this conflict.

My distress about grading comes from the expectations and norms of the institution [which] conflict violently with my beliefs and values about teaching.

Philosophical differences Two senior university professors, one a behaviorist and one a feminist, reflect with sadness upon the current economic/political pressures within which the academy "is a place increasingly being encouraged to become an industry" where students are viewed as "the product of our endeavor." In this competitive, "mega-plant" environment, the sociology professor perceives that "anomie and anxiety" have increased. She witnesses a "paranoid obsession with marks." Both of these professors lament the loss of an earlier climate of "discovery," "controversy" and intellectual experimentation.

Many of the professors in this study are keenly aware of the risks they take in order to practice non-traditional forms of pedagogy. Not only must they deal with the various constraints imposed by the institution, they are also often confronted with resistance from students to their method, content or personal views. For some, their chosen philosophy commits them to make such risky choices despite traditional academic beliefs and structures. While recognizing the need to be "very brave," one instructor is aware that "when we're stuck in institutions doing some of this stuff,....we're [at] the same time complicit while we're doing the critique." A "self-conscious" or reflective pedagogy, cognizant of the contradictions and open to the critique of students, is practiced by these instructors.

\section{Conclusions}

The story line or common theme in this research on the relationship of one's philosophy to one's practice is one of negotiation between what one assumes and believes to be true about teaching and the contextual factors (students, institution, and societal assumptions and beliefs) which serve as enablers or constrainers to playing out these assumptions and beliefs. Often these contextual 
factors and intervening conditions (for example, new or newly tenured professors) create some degree of conflict for professors in higher education.

The research indicates that one's philosophy of teaching influences the methods and strategies used in the classroom. Desired outcomes of teaching are defined differently depending on the philosophy that one holds. In this study, there are professors who define their role as expert, on one hand, and those who consider themselves co-learners and collaborative on the other. Those who feel qualitatively superior to students feel less constrained by the existing system and are satisfied with students' acquisition of knowledge as an outcome. Those who view students as experts in life experiences, but not necessarily in the subject matter at hand, want to promote personal growth or changed attitudes, assumptions and beliefs as students progress through their discipline. Those instructors who profess a critical pedagogy, aim to transform their students for the purpose of changing societal structures, policies, and practices in their chosen field. These instructors identify more constraints in teaching in a university system. They feel the most alienated and experience the most contradictions from the dominant pedagogical practices espoused in the university. They report that they must live with the consequences of their pedagogy such as isolation, labeling (e.g., the "Fem Police") and uncertainty. Thus, they are forced to transcend opposing forces and form a new synthesis between the old traditional ways of teaching in the classroom and action they believe is necessary to live out the philosophy they hold.

Further study on philosophy-in-action could make more explicit the complexity of teaching particularly for those who espouse alternative philosophies, assumptions and beliefs that guide their teaching practice. The university "community" needs to hear the many pedagogical voices - whether humanist, critical, feminist, or some combination of such voices - that are emerging alongside the more traditional pedagogies. Research on the various philosophies that undergird pedagogy can help instructors make explicit that which is implicit (knowing-in-action) as well as encourage reflection on the assumptions, beliefs, and attitudes that constitute one's philosophy-in-action. At a time when higher education is under review, the explication of one's philosophy of education can help us view teaching and learning not simply as the acquisition of techniques of teaching but as a foundation for what naturally evolves into one's pedagogy. The encouragement of multiple philosophies-in-action can also help the institution to evolve into learning spaces that meet the diverse needs of our learners. As we teach from various theoretical/philosophical frameworks, so our learners learn from various frameworks. Thus, students can be exposed to a wider range 
of teaching methods, techniques and devices which include acquisition of knowledge as well as critical thinking, personal growth and ultimately transformation of persons and social structures for the betterment of society.

\section{References}

Argyris, C. \& Schon, D. A. (1974). Theory in practice. San Francisco: Jossey-Bass. Bigge, M. L. (1982). Learning theories for teachers (4th ed.) Cambridge: Harper \& Row.

Brameld, T. (1965). Education for the emerging age: Newer ends and stronger means. New York: Harper \& Row.

Briskin, L. (1990). Feminist pedagogy: Teaching and learning liberation. Feminist Perspectives, No. 19. Ottawa: Canadian Research Institute for the Advancement of Women.

Briskin, L. \& Coulter, R. P. (1992). Introduction-Feminist pedagogy: Challenging the normative. Canadian Journal of Education, 17(3), 247-263.

Cranton, P. (1992). Working with adult learners. Toronto: Wall \& Emerson.

Elias, J. L. \& Merriam, S. (1980). Philosophical foundations of adult education. Malabar, FL: Krieger.

Gallagher, S. (1992). Hermeneutics and education. New York: SUNY.

Grundy, S. (1987). Curriculum: Product or praxis. Philadelphia: Falmer.

Hodgkinson, C. (1991). Educational leadership: The moral art. Albany: SUNY.

Kenway, J. \& Modra, H. (1992). Feminist pedagogy and emancipatory possibilities. In C. Luke, \& J. Gore, (Ed.) Feminisms and critical pedagogy. New York: Routledge.

Kneller, G. (1971). Introduction to the philosophy of education. Toronto: John Wiley \& Sons.

Knowles, M. (1984). The adult learner: A neglected species (3rd ed.). Houston: Gulf.

Kolb, D. A. (1984). Experiential learning. Englewood Cliffs: Prentice-Hall.

Lindeman, E. (1961). The meaning of adult education. Montreal: Harvest House. (original work published 1926).

McLaren, P. (1989). Life in schools: An introduction to critical pedagogy in the foundations of education. Toronto: Irwin.

Mezirow, J. (1991). Transformative dimensions in adult learning. San Francisco: Jossey-Bass.

Ozmon, H. A. \& Craver, S. M. (1986). Philosophical foundations of education. Toronto: Merrill.

Schon, D. A. (1983). The reflective practitioner: How professionals think in action. New York: Basic Books.

Shor, I. \& Freire, P. (1987). What is the "dialogical method" of teaching? Journal of Education, 169(3), 11-31.

Strauss, A. \& Corbin, J. (1990). Basics of qualitative research: Grounded theory procedures and techniques. Newbury Park: Sage. 